\title{
Biomonitoring of Effects Following Exposure of Fish to Sugar Refinery Effluent
}

\author{
Tugiyono (Corresponding author) \& Nuning Nurcahyani \\ Department of Biology, Faculty of Natural Sciences, University of Lampung, Indonesia \\ R. Supriyanto \& Sutopo Hadi (Corresponding author) \\ Department of Chemistry, Faculty of Natural Sciences, University of Lampung, Indonesia \\ E-mail: tugiyono64@unila.ac.id,sutopohadi@unila.a.c.id
}

Received: August 11, 2011

Accepted: August 26, 2011

doi:10.5539/mas.v5n5p39

\begin{abstract}
Biomarker is the newest concept in environmental biomonitoring. One of the key functions of biomarker is to provide an early warning signal of significant biological effects. The objective of this research was to determine biomarker as a water quality monitoring tool on the waste water treatment plant (WWTP). The experiment was conducted at waste water treatment plant ponds (WWTPs) of a sugar refinery by growing Nile tilapia in floating net cages for 60 days. Results show that CF and LSI decreased in all WWTP whereas the GSI value in first and second aeration ponds increased compared to the control fish. The SDH enzyme activity significantly increased in the first aeration and monitoring ponds compared to those of the other ponds. The most severe hyperemia in hepatic cells occurred in the first and second aeration ponds. The highest value of SGR and SR was observed in stabilization pond.
\end{abstract}

Keywords: Biomarker, SDH, Nile tilapia, Sugar refinery

\section{Introduction}

Changes in environmental quality can be identified based on changes in selected biological parameters. This approach in biomonitoring uses living organisms to monitor changes in biochemistry, physiology, morphology, and organism behavior instead of traditional approaches using community structure measures like abundance and diversity indices. Biomonitoring uses tools known as biochemical markers (biomarkers) to anticipate the impacts of pollution at the cellular and tissue level through to the level of population structure (Lam and $\mathrm{Wu}, 2003$ ).

A biomarker measures a biological response to chemical substances in the environment to give a measure of exposure and sometimes, also, of toxic effect (Walker et al., 1996). It is a biological tool used as a sensitive indicator demonstrating that toxicants have entered the organisms, been distributed within the tissues, and are eliciting a toxicological effect (McCarthy and Shugart, 1990). Biomarkers are the most-up-to-date tools used to estimate the impact of chronic exposure to specific or non-specific chemicals in the environment (Jørgensen, 1997). One of the main roles of biomarkers is to provide an early warning signal of significant biological effect (Lam and Gray, 2001). This study used the biomarker sorbitol dehydrogenase activity to assess the quality of water in waste water treatment ponds (WWTPs) of PT. Gunung Madu Plantation (PT.GMP), a large sugar refinery company in Lampung, Indonesia, using caged fish. Histopathology of the liver of the fish was assessed to confirm the biomarker results.

\section{Experiment}

\subsection{Fish Culture}

Twenty Nile tilapias (Oreochromis niloticus Linn) $(9.62 \pm 2.16 \mathrm{~g})$ were cultured in $1 \mathrm{~m} \times 1 \mathrm{~m} \times 1 \mathrm{~m}$ floating net cages placed in the WWTPs. Five ponds were used in this experiment, namely first and second aeration ponds, stabilization pond, monitoring pond and a control pond. The size and weight of each fish were measured prior to commencement of the experiment. The fish were kept for 60 days, were fed twice a day and any dead fish removed. At the end of 60 days, fishes were harvested and the following analyses were performed:

Standard growth rate (SGR) and Survival rate (SR) were calculated using the following equation (Gabche and Hockey, 1995; Gisbert and Williot, 1997): 
$S G R=\frac{\left(\ln W_{t}-\ln W_{O}\right)}{t} \times 100 \% \quad$ and $\quad S R=\frac{N_{t}}{N_{O}} \times 100 \%$

where $W o$ is weight or length in the first days or day to 0 ; Wt is weight or length in the day $\mathrm{t}$; $t$ is duration of maintenance (day), No is number of fish at day 0 , and $N t$ is number of harvested fish at day $\mathrm{t}$.

Physiological indices including condition factor (CF), liver somatic index (LSI) and gonadosomatic index (GSI) where calculated as follows:

$C F=\frac{\text { total body weight }}{(\text { total length })^{3}} \times 100 \quad($ Lucky, 1977, Gisbert and Williot, 1997).

$L S I=\frac{\text { liver weight }}{\text { body weight }} \times 100 \quad$ (Norrgren et al., 1999)

$G S I=\frac{\text { gonad weight }}{\text { body weight }} \times 100 \quad$ (Gabche and Hockey, 1995)

Sorbitol dehydrogenase enzyme (SDH) assay: The quantity of SDH was calculated from plasma/serum separated from blood or meat (muscle). Serum sorbitol dehydrogenase was analyzed UV-spectrophotometrically using Sigma Diagnostic Procedure No 50-UV. This method is based on the catalytic reduction of fructose to sorbitol with presence of NADH through the following reaction:

\section{SDH}

\section{D-Fructose $+\mathrm{NADH} \quad \Leftrightarrow \quad$ D-Sorbitol + NAD}

The rate of decrease in absorbance at $340 \mathrm{~nm}$ is a measure of SDH activity (Holdway et al., 1994; Webb and Gagnon, 2007).

Liver Histology: Each fish liver was fixated with $10 \%$ formalin solution, histological slices was made using conventional histological method (McManus and Mowry, 1964), and colored with haematoxylin and eosin (H\&E). The slices were photographed to identify any histological alteration.

\subsection{Analysis of Water Quality}

The physico-chemical quality of the water in the WWTP was measured daily (i.e temperature, $\mathrm{pH}$, chemical oxygen demands (COD), conductivity, total dissolved solid (TDS) and turbidity).

\subsection{Statistics}

Results are presented as means \pm standard error. Analysis of variance (ANOVA) and Least Significant Differences (LSD) was used to assess differences amongst treatments. $p<0.05$ was accepted for statistical significance.

\section{Results and Discussion}

\subsection{Growth and Survival rates}

The SGR of fish in all WWTP (first and second aeration ponds, stabilization and monitoring) were bigger compared to those of control. The SGR of fish in stabilization WWTP showed the highest amongst the other three WWTP ponds. It is also observed that the value of SR of all WWTP ponds is significantly higher compared to those of control (Table 1). These results indicated that the water conditions in the WWTP will successfully support fish life.

External factors (environment) that can influence fish growth are temperature and food availability. Results from this research showed that the temperature in all WWTP was in the range from $29^{\circ} \mathrm{C}-30^{\circ} \mathrm{C}$. This means that the water temperature in WWTP was normal. Hence, food availability will be the dominant factor to explain the increased size of the fish in the treatment ponds. Gabche and Hockey (1995) concluded that fish in an 
environment with excessive food will grow much faster than fish in comparable environments with less food availability.

\subsection{Physiological Indices}

The CF is a measure of the fattiness of the fish and allows comparisons to be made between populations living under different conditions. This physiological indicator may be affected if food is limited or if food consumption of the fish is impaired due to other stress factors. In addition the commercial value of the CF indicates the quality and quantity of meat and fish available to be eaten. So the condition factor can have either a biological or commercial meaning (Lucky, 1977). The CF recorded in the fish from the WWTP (first and second aeration, stabilization, and monitoring) was not significantly different $(p>0.05)$ compared to that of the control (Table 2). According to Lucky (1977), as the overall value of CF measured in this study was $\leq 1.7$, it means that fish were living in a depressed environment. Similarly the value of LSI of fish from the WWTP ponds that was lower than that of in control, but the difference was not significant $(p>0.05$; Table 2). The CF and LSI of rainbow trout fishes (Oncorhynchus mykiss) when fed by food mixed with astaxanthin was lower than that of in control (Rehulka, 2000). Finnegan et al. (2009) reported that snail living in the depressed environment (for instance exposed to irgarol) was less mobile and showed no responses.

GSI measured in the fish from the first and second aeration WWTPs was significantly greater $(p<0.05)$ than that of in control. While the GSI value of fish in the stabilization and monitoring WWTP was greater than that of in control, but the differences were not significantly different $(p<0.05$; Table 2$)$. GSI values amongst all WWTPs were not significantly different. This suggests that there was no interference in the development of Nile tilapia gonad living in WWTPs. The low value of GSI can be an indicator of a disturbance on reproductive ability, which in a long period can be a serious threat (Pointet and Miller, 2000; Webb, 2005).

\subsection{Activity of Sorbitol Dehydrogenase (SDH) Enzyme}

As shown in Figure 1, there was a significant increase $(p>0.05)$ of the SDH values at first aeration and monitoring of WWTP compared with those control. On the second aeration WWTP and stabilization WWTP showed an insignificant decrease $(p>0.05)$ in SDH value. The high SDH value at monitoring and first aeration WWTPs indicated potential liver cell damage in Nile tilapia due to exposure to polluted material (xenobiotic). In the second aeration and stabilization WWTPs, on the other hand, showed the opposite results. Ozretic and Ozretic (1993) reported that under normal conditions the concentration of SDH in the plasma was very low. Therefore the increase of SDH concentration in plasma was an indicator of liver cell damage. The damage to liver cells can be measured with alanine aminotransferase (ALT) plasma, SDH activity and histopathology of the liver cells (Kulkarni et al., 1996). Fish captured from the Port Philip Bay, Victoria, showed increased SDH serum activity due to high levels of pollution (Holdway et al., 1994). Previous studies using pink snapper (Pagrus auratus), injected with $100 \mu \mathrm{g}$ PCB 126, demonstrated no significant difference in SDH activity value with that of the control fish (Tugiyono and Gagnon, 2002). Black bream from 5 different locations along the river Swan River, Perth, Western Australia showed that the value of SDH did not differ significantly (Webb et al., 2005).

\subsection{Histology}

Liver histology reveals the following in fish from the first and second aeration WTTPs: (1) there is congestion or hyperemia causing blockage of a blood vessel or sinusoid in the small vena that increasing blood volume. Hyperemia also occurs in fishes kept in the remaining WTTPs and control pond, but to a lesser degree. (2) There is necrosis (cell death) whereby the nucleus of the liver cells demonstrates karyoresist, karyolysis, and karyopycnosis although karyoresist dominates), (3) Infiltration and accumulation of cellular inflammation near vena centralist is apparent.

The liver cells of fish kept in the stabilization and monitoring ponds showed light congestion. This indicated that cells were in relatively good condition with the cells still intact in both sexes. This coincides with the fish in those ponds (stabilization and monitoring) having the highest value in both standard growth rate and survival rate (Table 1) compared to the remaining ponds. This was further validated by SDH analysis which showed that the SDH value in the stabilization pond was smaller than that of the remaining ponds, especially first aeration pond (Figure 2). Earlier research demonstrated that pink snapper injected with $100 \mu \mathrm{g}$ PCB-126 experienced fatty change which is a further sign of cellular damage (Tugiyono and Gagnon, 2002). Previously, we reported that fish captured from the stabilization and monitoring WTTP pond in PT. Gunung Madu Plantation sugar refinery also indicated the occurrence of fatty change (Tugiyono et al., 2009). 
Fatty change is caused by hypoxemia due to impacts of toxins on the liver cell which result in a decrease in oxygen to the liver cells. The hypoxemic liver cells cannot burn fat and therefore upset the function of cells. Hypoxemia fatty changes usually cam be identified from the interruption of blood circulation due to congestion. This congestion results in the accumulation of fat in liver cells (Hibia, 1982).

\subsection{Analysis of Water Quality}

The SGR, SR, SDH and histopathological results are also supported by analysis of water quality. The stabilization and monitoring WTTP had good water quality (Total Dissolved Solid and turbidity) relative to the three other ponds (Table 3$)$, although the difference was not significant $(p<0.05)$.

The concentration of organic material in the monitoring and control ponds was higher compared to the other WWTPs, although the difference was not significant $(p>0.05)$. This showed there was increased organic material in the monitoring and control ponds. The high value of COD indicates the existence of organic material in water (Hellawel, 1989).

\section{Conclusion}

The fish from the first aeration WWTP had indications of liver damage as measured by high SDH activity and evident histopathological changes. The fish in the second aeration pond also displayed adverse histology however this was not reflected in SDH activity. The biomarker and histology show that the stabilization pond had water quality conducive to fish growth.

\section{Acknowledgements}

The authors would like to thank to The Directorate of Research and Community Services, Directorate General of Higher Education, The Ministry of National Education of Republic of Indonesia that provided fund for this project through Fundamental Research Grant Scheme 2007 with contract number of 28/SP2H/PP/DP2M/III/2007 and The Competitive Research Grant for International Publication 2009. Thanks also go to PT. Gunung Madu Plantation that allowed to a field study and Diane Webb, Ph.D, Curtin University of Technology, Perth Western Australia, for proof reading the manuscript.

\section{References}

Finnegan, M.C., Pittman, S. and DeLorenzo, M.E. (2009). Lethal and sublethal toxicity of the antifoulant compound Irgarol 1051 to the mud snail Llyanassa obsolete. Archives of Environmental Contamination and Toxicology, 56(1):85-95. PMID: 18458994 [PubMed - indexed for MEDLINE].

Gabche, C.E. and Hockey, H.U.P. (1995). Growth, mortality and reproduction of Sardinella maderensis (Lowe, 1841) in the artisanal fisheries off Kribi, Cameroon. Fisheries Research, 24:331-344. doi:10.1016/0165-7836(95)00371-7, http://dx.doi.org/10.1016/0165-7836(95)00371-7

Gisbert, E. and Williot, P. (1997). Larval behaviour and effect of timing of initial feeding on growth and survival of Siberian sturgeon (Acipenser baeri) larvae under small scale hatchery production. Aquaculture, 156:63-75. doi:10.1016/S0044-8486(97)00086-0, http://dx.doi.org/10.1016/S0044-8486(97)00086-0

Hibia, T. (1982). An atlas of fish histology: normal and pathological features. Gustav Fischer. New York.

Holdway, D.A., Brenann, S.E. and Ahokas, J.T. (1994). Use of hepatic MFO and blood enzyme biomarkers in sand flathead (Platycephalus bassensis) as indicators of pollution in Port Phillip Bay Australia. Marine Pollution Bulletin, 28(11):683-695. doi:10.1016/0025-326X(94)90304-2, http://dx.doi.org/10.1016/0025-326X(94)90304-2

Holdway, D.A., Brennan, S.E., Haritos, V.S., Brumley, C.M. and Ahokas, J.T. (1998). Development and evaluation of standardized methods for using liver MFO enzymes in two Australian marine fish as biomarkers of xenobiotic exposure. National Pulp Mills Research Program Report, 24:1-33.

Hellawel, J.M. (989). Biological Indicators of freshwater pollution and environmental managements. Elsevier Science Publishers LTD, New York.

Jorgensen, S.E. (1997). Ecotoxicological research - Historical development and perspectives. In: Schuurmann G, Markert B (eds) Ecotoxicology: Ecological fundamentals, chemical exposure, and biological effects. John Wiley \& Sons, Inc. New York, pp 3-15.

Kulkarni, S.G., Duong, H., Gomila, R. and Mehendale, H.M. (1996). Strain differences in tissue repair response to1,2 dichlorobenzene. Archives of Toxicology, 70:714-723. doi:10.1007/s002040050332, http://dx.doi.org/10.1007/s002040050332 
Lam, P.K.S. and Wu, R.S.S. (2003). Use of biomarkers in environmental monitoring. Presented at the STAP Workshop on The Use Bioindicators, Biomarkers and Analytical Methods for Analysis of POPs in Developing Countries, Tokyo, 10-12 December 2003.

Lam, P.K.S. and Gray, J.S. (2003). The use of biomarkers in environmental monitoring programmers. Marine Pollution Bulletin, 46:182-186. http://dx.doi.org/10.1016/S0025-326X(02)00449-6

doi:10.1016/S0025-326X(02)00449-6,

Lucky, Z. (1977). Method for the diagnosis of fish diseases. Amerind Publishing Co. Put. Ltd New Delhi. P 137.

McCarthy, F.J. and Shugart, L.R. (1990). Biological markers of environmental contamination. In: McCarthy FJ, Shugart LR (eds). Biomarkers of environmental contamination. Lewis Publishers. Boca Raton, Florida, pp 1-14.

McManus, J.F.A. and Mowry, R.W. (1964). Staining method histologic and histochemical. Harper \& Row, New York and John Wentherhill, Inc. Tokyo. P 423.

Norrgren, L., Blom, A., Andersson, P.L., Borjeson, H., Larsson, D.G.J. and Olsson, P.E. (1999). Effects of potential xenoestrogens (DEHP, nonylphenol and PCB on sexual differentiation in juvenile Atlantic salmon (Salmo salar). Aquatic Ecosystem Health and Management, 2:311-317. doi:10.1080/14634989908656967, http://dx.doi.org/10.1080/14634989908656967

Ozretic, B. and Ozretic, M.K. (1993). Plasma sorbitol dehydrogenase, Glutamate dehydrogenase and alkaline phosphatase as potential indicator of liver intoxication in Grey Mullet (Mugil auratus Risso). Bulletin of Environmental Contamination and Toxicology, 50:586-592. doi:10.1007/BF00191250, http://dx.doi.org/10.1007/BF00191250

Rehulka, J. (2000). Influence of astaxanthin on growth rate, condition, and some blood indices of rainbow trout Oncorhynchus mykiss. Aquaculture, 190:27-47. doi:10.1016/S0044-8486(00)00383-5, http://dx.doi.org/10.1016/S0044-8486(00)00383-5

Tugiyono and Gagnon, M.M. (2002). Metabolic disturbances in fish exposed to sodium pentachlorophenate (NaPCP) and 3,3',4,4',5-pentachlorobiphenyls (PCB126), individually or combined. Comparative Biochemistry and Physiology C: Toxicology and Pharmacology, 132:425-435. doi:10.1016/S1532-0456(02)00091-1, http://dx.doi.org/10.1016/S1532-0456(02)00091-1

Tugiyono, Nurcahyani, N., Supriyanto, R. and Kurniati, M. (2009) Biomonitoring of waste water treatment plant of PT. Gunung Madu Plantation Lampung Indonesia sugar refinery using biomarker: physiology index and liver histological alteration in Nile tilapia. Jurnal Sains MIPA, 15:42-50 (Indonesian).

Walker, C.H. (1996). The use of biomarkers to measure the interactive effects of chemicals. Ecotoxicology and Environmental Safety, 40:60-70. doi:10.1006/eesa.1998.1643, http://dx.doi.org/10.1006/eesa.1998.1643

Webb, D., Gagnon, M.M. and Rose, T. (2005). Interseasonal variability in biomarkers of exposure in fish inhabiting a Southwestern Australian Estuary. Environmental Toxicology, 20:522-532. doi:10.1002/tox.20141, http://dx.doi.org/10.1002/tox.20141

Webb, D. and Gagnon, M.M. (2007). Serum sorbitol dehydrogenase activity as an indicator of chemically induced liver damage in black bream (Acanthopagrus butcheri). Environmental Bioindicators, 2(3):172-182. doi:10.1080/15555270701591006, http://dx.doi.org/10.1080/15555270701591006

Table 1. Standard growth rate (SGR) and survival rate (SR) at WWTPs, PT. Gunung Madu Plantation, Lampung, Indonesia

\begin{tabular}{|l|c|c|}
\hline WWTP ponds & SGR (\%) & SR (\%) \\
\hline First aeration & 1.705 & 85 \\
\hline Second aeration & 1.719 & 95 \\
\hline Stabilization & 2.259 & 95 \\
\hline Monitoring & 1.988 & 93.75 \\
\hline Control & 1.153 & 75 \\
\hline
\end{tabular}


Table 2. Physiological indices of fish caged in WWTPs, PT. Gunung Madu Plantation, Lampung, Indonesia

\begin{tabular}{|l|l|l|l|}
\hline \multirow{2}{*}{ WWTP ponds } & \multicolumn{3}{|c|}{ (Means \pm SE) } \\
\cline { 2 - 4 } & \multicolumn{1}{|c|}{ CF } & \multicolumn{1}{c|}{ LSI } & \multicolumn{1}{c|}{ GSI } \\
\hline First aeration & $1.575 \pm 0.124^{\mathrm{a}}$ & $2.84 \pm 0.789^{\mathrm{a}}$ & $3.643 \pm 2.948^{\mathrm{a}}$ \\
\hline Second aeration & $1.522 \pm 0.147^{\mathrm{a}}$ & $3.376 \pm 2.063^{\mathrm{a}}$ & $5.272 \pm 2.971^{\mathrm{a}}$ \\
\hline Stabilization & $1.592 \pm 0.269^{\mathrm{a}}$ & $2.748 \pm 0.759^{\mathrm{a}}$ & $2.628 \pm 2.433^{\mathrm{ab}}$ \\
\hline Monitoring & $1.585 \pm 0.191^{\mathrm{a}}$ & $3.658 \pm 1.259^{\mathrm{a}}$ & $2.298 \pm 1.689^{\mathrm{ab}}$ \\
\hline Control & $1.578 \pm 0.168^{\mathrm{a}}$ & $3.679 \pm 1.787 \mathrm{a}$ & $1.008 \pm 0.586^{\mathrm{b}}$ \\
\hline
\end{tabular}

Note: The same letter in the same column shows no significant differences $(p \geq 0.05)$.

Table 3. Water quality conditions at WWTPs PT. Gunung Madu Plantation. Lampung. Indonesia

\begin{tabular}{|l|l|l|l|l|l|}
\hline WWTP ponds & $\mathrm{pH}$ & COD $(\mathrm{mg} / \mathrm{l})$ & Cond & TDS $(\mathrm{mg} / \mathrm{l})$ & $\begin{array}{l}\text { Turbidity } \\
\text { (NTU) }\end{array}$ \\
\hline First aeration & $8.27 \pm 0.20 \mathrm{~b}$ & $75.56 \pm 7.44 \mathrm{a}$ & $780.89 \pm 98.04 \mathrm{c}$ & $390.44 \pm 49.02 \mathrm{c}$ & $25.56 \pm 5.86 \mathrm{a}$ \\
\hline $\begin{array}{l}\text { Second } \\
\text { aeration }\end{array}$ & $8.74 \pm 0.32 \mathrm{c}$ & $76.11 \pm 5.42 \mathrm{a}$ & $700.78 \pm 72.81 \mathrm{bc}$ & $344.00 \pm 37.81 \mathrm{bc}$ & $26.56 \pm 5.92 \mathrm{a}$ \\
\hline Stabilization & $8.83 \pm 0.18 \mathrm{c}$ & $77.11 \pm 5.39 \mathrm{a}$ & $668.00 \pm 65.91 \mathrm{ab}$ & $333.89 \pm 33.06 \mathrm{ab}$ & $20.33 \pm 3.94 \mathrm{a}$ \\
\hline Monitoring & $8.28 \pm 0.08 \mathrm{~b}$ & $82.86 \pm 5.67 \mathrm{a}$ & $651.29 \pm 32.78 \mathrm{ab}$ & $325.71 \pm 16.32 \mathrm{ab}$ & $25.43 \pm 4.40 \mathrm{a}$ \\
\hline Control & $7.72 \pm 0.16 \mathrm{a}$ & $80.43 \pm 6.40 \mathrm{a}$ & $588.86 \pm 18.12 \mathrm{a}$ & $294.29 \pm 8.96 \mathrm{a}$ & $21.86 \pm 3.02 \mathrm{a}$ \\
\hline
\end{tabular}

Note: The same letter on the same column show no significant differences $(p \geq 0.05)$.

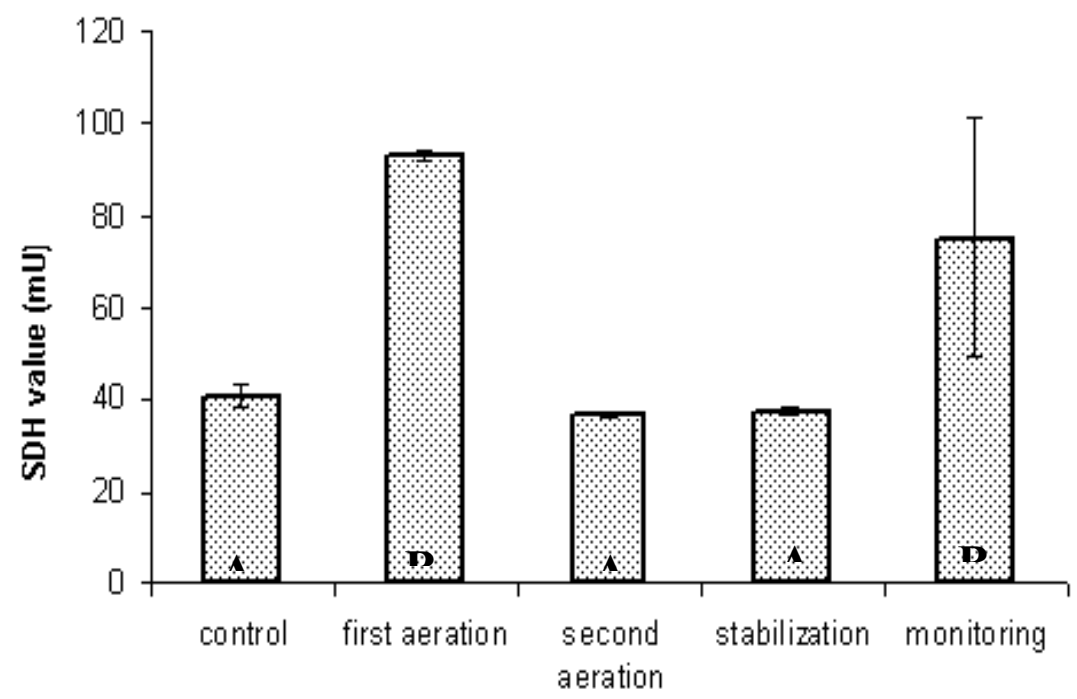

WWTP Ponds

Figure 1. Sorbitol Dehydrogenize (SDH) enzyme activities at the WWTPs PT. Gunung Madu Plantation. Lampung. Indonesia. The same letter on each bar indicates no significant differences at $(p \geq 0.05)$ 

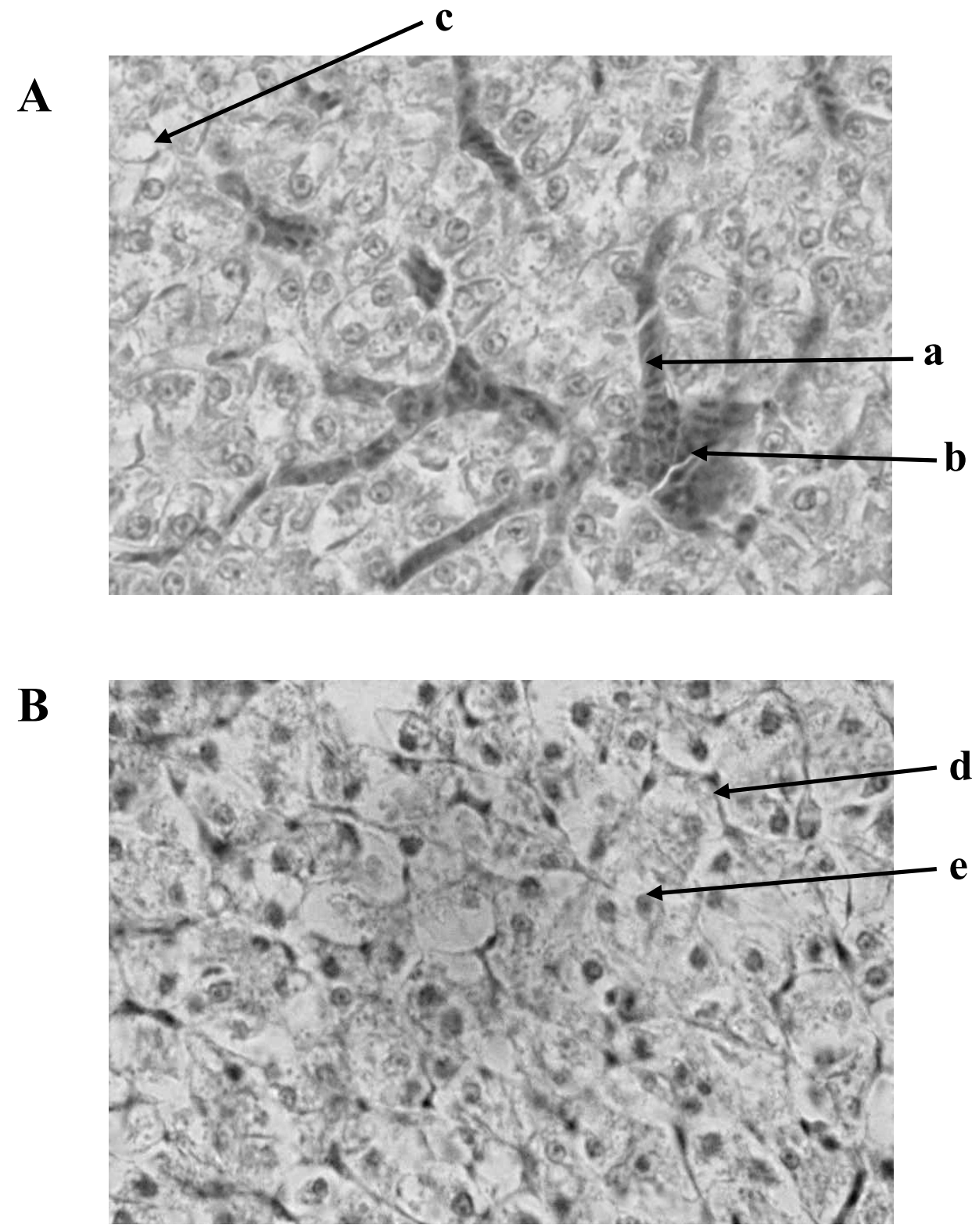

Figure 2. (A) Histological preparation of liver cells in Nile tilapia collected from WWTPs PT. Gunung Madu Plantation. Lampung. Indonesia (a) hyperemia (congestion) in the sinusoid or blood vessel cells in the small vena. (b) infiltration (cellular inflammation) near the vena centralist. and (c) fatty change in liver from fish in the first and second aeration WWTP. (B) Hepatocyte cell from fish in the control pond: (d) nuclei (e) membrane cell. HE X 400 